\title{
Марина Тригук
}

Брестский государственный университет имени А. С. Пушкина (Брест, Беларусь)

\section{РОЛЬ ПРИЧАСТИЙ В ХУДОЖЕСТВЕННЫХ ТЕКСТАХ т. ТОЛСТОЙ}

Причастие - особая неспрягаемая форма, входящая в состав русского глагола. Она выражает действие как наличный атрибутивный признак предмета, проявляющийся во времени. В. В. Виноградов называл причастия «гибридными формами-словами», «потоком форм», который идет непосредственно от глагола и внедряется в систему прилагательных.

В отличие от других форм причастие имеет комплекс категорий, который связывает его и с глаголом, и с прилагательным одновременно. Категории времени (настоящего и прошедшего), вида и залога, переходности / непереходности объединяют причастие с категориальным и лексическим значением исходного глагола. Словоизменительные категории рода, числа, падежа, краткая и полная форма указывают на сходство с прилагательным. Кроме разнообразных категорий, причастие обладает широкими синтаксическими возможностями. Оно может выступать в роли определения или части составного сказуемого, употребляться одиночно или в сочетании с зависимыми словами, занимать позицию до или после определяемого слова.

Стилистические возможности причастия характеризуются неоднозначно. Изначально употребление причастий связано с влиянием церковнославянского языка как образца письменной речи. В истории русского языка был период, когда причастия осознавались как формы, присущие только «высокому стилю» речи. М. В. Ломоносов считал недопустимым употребление причастий, образованных от глаголов, называвших обыденные бытовые действия. В настоящее время причастия являются приметой книжных стилей и не употребляются в разговорной речи. В книжной речи, в частности официально-деловой и научной, причастия служат для экономии языковых усилий, позволяя лаконично и точно выразить необходимый смысл.

Художественная речь содержит разнообразные примеры употребления причастий, хотя ведется дискуссия относительно уместности упо- 
требления данных форм. М. Горький считал нежелательными причастия из-за неблагозвучности и последовательно заменял их в черновиках своих произведений. В то время как А. С. Пушкин подчеркивал уместность причастий, говоря об их выразительной краткости. По мысли лингвиста А. М. Пешковского, глагол уступает место причастию при необходимости (Пешковский 1959: 110). Согласно И. Б. Голуб, современные писатели ценят причастия не за их книжный характер, а за то, что в них аккумулируется значительная выразительная энергия русского языка (Голуб 1997). Разнообразие лексических значений глаголов, от которых образуются причастия, синтаксических связей и функций причастий, в сочетании с окружающим контекстом лежит в основе выразительных возможностей данной формы.

В художественных текстах Т. Толстой причастия достаточно распространены. Полные страдательные причастия чаще употребляются в постпозитивных оборотах, выражая признак, связанный с конкретным физическим действием: Там еще лежало сено, накошенное Янсоном за год до смерти Сталина. Обстоятельство времени и форма творительного падежа субъекта поддерживают глагольность причастия.

Препозитивные причастные обороты используются для характеристики среды или субъекта: ... лежала, растертая и просыпанная временем, пыль неопџоннаваемоге. неизвестно чьего, какого-то чего-то. Творительный падеж не выражает значения субъекта, поэтому конструкция является квазипассивной. Причастный оборот употреблен в метафорическом значении, что характерно для идиостиля Т. Толстой: И толстая тетка, завуч, - не человек, а слипшиеся комья, - всегда одетая в один и тот же приличный синий чехол, тоже разинет из первого ряда свой отремонтированный, подбитый сталью рот: $x a-x a-x a$.

Употребление страдательного причастия как согласованного препозитивного определения не является основным. В этой позиции оно в наибольшей мере подвергается адъективации, выражая признак конкретного предмета: Приоткрыты ротики - зубастые моллюски; затененные глаза любуются сами собой. Субъект действия не подразумевается в контексте, сама конструкция выражает значение качественного признака. О значении качественности свидетельствует возможность привести антоним (затененные глаза выразительные глаза), подобрать наречие меры и степени (полностью затемненные глаза). Качественный признак усиливается, если причастие выступает в однородном ряду с прилагательными: ... ненужный больше ни одному человеку на этом новом, отбеленном, отстиранном, продезинфицированном свете, он ушел, наверное, навсегда и непоправимо ...

Составное именное сказуемое с полным страдательным причастием употребляется реже, чем сказуемое с краткой причастной формой. Сказуе- 
мое с полной формой страдательного причастия может обозначать психическое состояние субъекта: Как заколдованная стоит толпа грешников, подняв вверх лища. В этом примере причастие в составе сказуемого является сравнительным оборотом.

В позиции сказуемого краткие страдательные причастия могут употребляться в сочетании с творительным падежом орудия действия и именительным падежом объекта, которые подчеркивают пассивное значение причастия: Янсон рассеялся, распался, ушел в землю, его мир был уже давно и плотно завален мусором четырех поколений мира нашего. Тексты Т. Толстой содержат больше примеров конструкций со сказуемым страдательным причастием без творительного падежа субъекта или орудия действия: $У$ него замкнутое и терпеливое лицо, как у всех слепьх, веки сомкнуты, голова опущена, ухо он склонил к своей спутнице; Красныле от крика лица склонились надо мной, ртыл разинуты, - сквозь лебеду десятилетий не сльиу, не помню, не понимаю слов... В значении причастия в этом случае актуализируется сема результативного состояния. В приведенных примерах дается характеристика внешнего облика. Такая конструкция может выражать и характеристику морального состояния: Это когда все теплое, домашнее, хорошее и уютное вытащено спросонья на мороз, осмеяно, подвергнуто оскорблениям; Чтото, - не знаю что, - оскорблено и бунтует во мне. В. В. Виноградов характеризовал такое употребление значением качественного состояния, особенно при ослаблении глагольности.

Действительные причастия характеризуют те определяемые слова, которые имеют значение субъекта действия, активного носителя признака. Причастные обороты, стоящие в постпозиции к определяемому слову, обычно обозначают действия лица или предмета: И на уроках пения поют и поют про каких-то мертвых орлят, пионеров, партизан, солдат, якобы храбрых мальчишек, заползающцх в тыл непроясненному врагу...; И хорошо ещзе, если позволят просто сидеть на деревянных откидных стульях, прищемляющих то пальцы, то платье, - а ну как заставят выступать? Глагольное управление, сохраняющееся у причастий, расширяет выразительность их атрибутивных возможностей.

Причастный оборот, передающий характеристику предмета, может являться метафорой, создавая художественный образ: Я подхожу к дому, высящемуся надо мной серой громадой: окна уже зажглись, хлопья вечерней музыки валятся из форточек... Я иду домой, проходными дворами, мимо почерневших и осевших сугробов, и по Кировскому проспекту ... и через мостик, и мимо цыганок, темными тенями стоящими на перекрестках... Причастия, употребленные как ряд однородных членов, могут реализовывать прием градации: Берет - та же каска, только мягкая, смягчившаяся, уступившая и отступившая, уменьшившаяся в размерах, податливая; Вместо платьев - ночные сорочки, вместо шляп - волосы, волосы, волосьл. 
Распущенные, висящие, болтающиеся, развевающиеся на ветру. В препозиции причастный оборот также может давать метафорическую характеристику предмета: Белье водовороты тел увенчаны шляпами, каждая как клумба, как сад, как взбегающий на гору город.

Одиночные причастия в препозиции в текстах Т. Толстой обычно дают качественную характеристику предмета: валик поредевших волос, банка засохшей олифы, коробки со слипшимися гвоздями. Глаголы поредеть, засохнуть, слипнуться - это непереходные глаголы совершенного вида. В. В. Виноградов подчеркивал, что у причастий, образованных от таких глаголов, есть сильная качественная составляющая. Качественность усиливается при употреблении причастия в ряду однородных членов с качественным прилагательным: ...иистый, обрусевший швед, он уютно и любовно устроил себе спаленку, - частный уголок, толстая дверь с тяжелым шпингалетом, под полом - свои, чистые куры. Мыс сорвали всю бумагу, всю подчистую, мы прошлись наждачной шкуркой по босым, оголившимся доскам; азарт очищения охватил все четыре поколения, мы терли и терли.

Обычно причастия относятся к существительному в любой его синтаксической функции (подлежащего, дополнения, именной части сказуемого и др.). Употребляясь без существительных, причастия субстантивируются: В каждом итальянском храме на стене висит коробка для денег - дополнительная услуга для интересующцхся; Все как всегда ... ещце не вылупился из коммерческого яйца Лев Новоженов со товарищи, еще не приучил толпу наслаждаться изысканным остроумием, о которым презентуются раздавленные и оплеванные, униженные и оскорбленные. В приведенных примерах субстантивированные причастия обозначают группу лиц как совокупность. В первом примере у субстантивированного причастия для интересующихся глагольная семантика заглушается и одновременно усиливается значение предметности. Однако во втором случае к субстантивированным причастиям раздавленные и оплеванные, униженные и оскорбленные может быть восстановлен творительный падеж со значением субъекта действия, что свидетельствует о сохранении глагольности в большей степени.

Таким образом, в текстах Т. Толстой причастия непосредственно участвуют в создании художественных образов. Во-первых, одиночные причастия и причастия в составе оборотов выполняют изобразительную функцию, характеризуя лицо, предмет или окружающую среду. Во-вторых, данные формы, при содействии лексического значения и грамматических характеристик, оформляют метафоры и сравнения, создают прием градации, являясь компонентом образных средств. 


\section{Библиография}

Голуб И. Б. (1997), Стилистика русского языка, http://www.hi-edu.ru/e-books/xbook028/01/ about.htm.

Замятина И. В. (2010), Грамматика русского причастия: автореферат на соискание степени кандидата филологических наук, Москва.

Пешковский А. М. (1959), Избранные труды, Москва.

Скворцова Н. (2014), «Отказаться нельзя употреблять», или Причастия в художественном тексте, [в:] ред. В. И. Ивченков, Слова у кантэксие часу, Минск, с. 85-91.

Толстая Т. (2007), День. Личное, Москва.

Maryna Tryhuk

THE ROLE OF PARTICIPLES IN THE ART TEXTS BY T. TOLSTAYA

(Summary)

The article deals with the role of participles in the art texts by T. Tolstaya. Examples of the use of active and passive participles in a variety of syntactic constructions are given. Particles are also described as part of speech figures. Use of participles as the mean of creation of art image in art stories of $\mathrm{T}$. Tolstaya is pointed out.

Keywords: art text, T. Tolstaya, participle.

\section{РОЛЬ ПРИЧАСТИЙ В ХУДОЖЕСТВЕННЫХ ТЕКСТАХ Т. ТОЛСТОЙ}

(Резюме)

Статья посвящена анализу роли причастий в художественных текстах Т. Толстой. Приводятся примеры употребления причастий активного и пассивного залога в различных синтаксических конструкциях. Отмечается включение причастий в состав художественных образных средств. Делается вывод о значимости причастий как средства создания художественного образа в рассказах писателя.

Ключевые слова: художественный текст, Т. Толстая, причастие. 